\title{
Szacowanie wartości współczynnika przewodności cieplnej piaskowców fliszowych na podstawie składu mineralnego
}

\begin{abstract}
W ramach przedstawionej pracy przeprowadzono analizę modeli matematycznych umożliwiających ocenę wartości współczynnika przewodności cieplnej skały na podstawie składu mineralnego i porowatości. Zastosowano różnego rodzaju modele, od najprostszych, zakładających warstwową budowę skały, do bardziej skomplikowanych modeli inkluzji sferycznych. Wartości obliczone porównano z danymi laboratoryjnymi. Uzyskane wyniki umożliwiły dobór optymalnych modeli służących do obliczenia przewodności cieplnej piaskowców fliszowych.
\end{abstract}

Słowa kluczowe: przewodność cieplna, modele matematyczne, skład mineralny.

\section{Estimating the thermal conductivity value of the Carpathian flysch sandstones on the basis of their mineral composition}

\begin{abstract}
Mathematical models for the estimation of the thermal conductivity of rocks on the basis of their mineral composition and porosity were analyzed in the presented work. Different types of models from the simplest, layer models to more complex spherical inclusion models were introduced. Calculated values were compared with the laboratory data. The obtained results enabled the selection of the most effective models for the calculation of the thermal conductivity of flysch sandstones.
\end{abstract}

Key words: thermal conductivity, mathematical models, mineral composition.

\section{Wstęp}

Określenie przewodności cieplnej skał jest niezbędne do scharakteryzowania warunków termicznych basenu sedymentacyjnego. Chcąc uzyskać wiarygodne wyniki oznaczeń przewodności cieplnej, należy wziąć pod uwagę zróżnicowanie własności cieplnych skał o odmiennej litologii. Badania laboratoryjne przewodności cieplnej skał wykonywane są punktowo, w miarę dostępności rdzenia wiertniczego, i wymagają próbek o dużych rozmiarach (plasterek o grubości około $2 \mathrm{~cm}$ i średnicy lub boku $5 \mathrm{~cm}$ ), co często ogranicza liczbę wykonywanych pomiarów. Ocena wartości przewodności cieplnej na podstawie składu mineralnego umożliwia oszacowanie tego parametru w profilu otworów, w których nie dysponujemy odpowiednią ilością materiału rdzeniowego. Możliwość oceny współczynnika przewodności cieplnej na podstawie mineralogii jest też bardzo istotna w przypadku badania materiału skalnego $\mathrm{z}$ odsłonięć powierzchniowych i z płytkich odwiertów (do $100 \mathrm{~m}$ ), wykonywanych dla celów geotermii niskotemperaturowej. Materiał skalny z opisanych powyżej lokalizacji może być zwietrzały lub słabo zwięzły, co znacznie utrudnia lub wręcz uniemożliwia przeprowadzenie laboratoryjnych pomiarów współczynnika przewodności cieplnej.

\section{Podstawy teoretyczne}

Przewodność cieplna skały jest funkcją składu mineralnego i porowatości, jej wartość zależy od zawartości i przewod- ności cieplnej budujących ją minerałów oraz roztworów porowych. Jako wielkość wektorowa, zależy również od geometrii 
przestrzeni porowej, od takich czynników jak: kształt i wielkość porów oraz dystrybucja poszczególnych minerałów w skale. Do oceny przewodności cieplnej stosowane są różnego rodzaju modele oparte na pewnym uproszczeniu wewnętrznej geometrii (struktury) skał $[8,9,16]$, umożliwiające wyliczenie przewodności cieplnej skały na podstawie własności jej składników. Modele te wykorzystywane są zarówno do przeliczania wartości przewodności cieplnej próbki suchej na nasyconą roztworami porowymi [4, 16, 18], jak i do charakterystyki przewodności cieplnej skały na podstawie przewodności cieplnej budujących ją minerałów [5, 7, 9, 10, 13, 16, 17].

W najprostszym przypadku skała może być opisana w postaci modelu warstwowego [10, 16, 18], w którym warstwy reprezentują poszczególne składniki skały. Przewodność cieplna dla przepływu ciepła zachodzącego równolegle do warstw określona jest przez średnią arytmetyczną $\left(\lambda_{\text {aryt }}\right)$, wyznaczającą górną granicę badanej wartości:

$$
\lambda_{\text {aryt }}=(1-\phi) \lambda_{m}+\phi \lambda_{p}
$$

gdzie:

$\lambda_{m}$ - przewodność cieplna szkieletu ziarnowego [W/mK], $\lambda_{p}-$ przewodność cieplna roztworów porowych $[\mathrm{W} / \mathrm{mK}]$, $\phi$ - porowatość [\%].

Przewodność cieplna dla przepływu ciepła zachodzącego prostopadle do warstw określona jest przez średnią harmoniczną $\left(\lambda_{\text {harm }}\right)$, określającą dolną granicę badanej wartości:

$$
\lambda_{\text {harm }}=\left[(1-\phi) \lambda_{m}^{-1}+\phi \lambda_{p}^{-1}\right]^{-1}
$$

Modele warstwowe zakładające przepływ ciepła zachodzący równolegle i prostopadle do uwarstwienia określają więc wartości skrajne - granice, między którymi mieszczą się rzeczywiste wartości przewodności cieplnej [10, 16, 18].

Zawężenie zakresu wartości przewodności cieplnej określonego przez modele warstwowe umożliwia zastosowanie granic Hashina-Shtrikmana [4, 10, 18]. Model Hashina-Shtrikmana zakłada homogeniczność i izotropowość ośrodka skalnego. Granice H-S odpowiadają takiej geometrii skały, w której szkielet ziarnowy reprezentowany jest przez sferyczne ziarna rozproszone w roztworze porowym (dolna granica $\left.-\lambda_{\mathrm{HS}-}\right)$ lub w której roztwór porowy ograniczony jest do sferycznych inkluzji w matrix (górna granica $-\lambda_{\mathrm{HS}^{+}}$):

$$
\begin{aligned}
& \lambda_{\mathrm{HS}-}=\lambda_{p^{+}}+\frac{1+\phi}{\left(\frac{1}{\left(\lambda_{m}-\lambda_{p}\right)}\right)+\left(\frac{\phi}{3 \lambda_{p}}\right)} \\
& \lambda_{\mathrm{HS}+}=\lambda_{m^{+}}+\frac{\phi}{\left(\frac{1}{\left(\lambda_{p}-\lambda_{m}\right)}\right)+\left(\frac{1-\phi}{3 \lambda_{m}}\right)}
\end{aligned}
$$

Jednym z modeli uwzględniających strukturę skały opisywanych w literaturze jest model sferycznych inkluzji Clausiusa-Mossottiego [16]. Model dla skały składającej się ze sferycznych inkluzji o przewodności cieplnej $\lambda_{1}$ rozproszonych w materiale bazowym o przewodności cieplnej $\lambda_{2}$ określony jest przez równanie:

$$
\frac{\lambda-\lambda_{2}}{\lambda+2 \lambda_{2}}=V \cdot \frac{\lambda_{1}-\lambda_{2}}{\lambda_{1}+2 \lambda_{2}}
$$

gdzie:

$V$ - objętość inkluzji sferycznych $\left[\mathrm{cm}^{3}\right]$,

$\lambda$ - przewodność cieplna całej skały [W/mK].

W przypadku gdy składnikiem podstawowym jest szkielet ziarnowy o przewodności cieplnej $\lambda_{m}$, a roztwory porowe o przewodności cieplnej $\lambda_{p}$ występują w postaci sferycznych inkluzji (model analogiczny do górnej granicy $\mathrm{H}-\mathrm{S}$ ), równanie przyjmuje postać:

$$
\lambda_{s f_{-} m}=\lambda_{m} \frac{(2 \eta+1)-2 \phi(\eta-1)}{(2 \eta+1)+\phi(\eta-1)}
$$

gdzie: $\eta=\lambda_{m} / \lambda_{p}$.

Dla skały złożonej ze sferycznych ziaren zanurzonych w roztworze porowym (model analogiczny do dolnej granicy $\mathrm{H}-\mathrm{S}$ ) otrzymujemy równanie:

$$
\lambda_{s f_{-} r}=\lambda_{p} \frac{3 \eta-2 \phi(\eta-1)}{3+\phi(\eta-1)}
$$

Do wyznaczania przewodności cieplnej skały na podstawie przewodności cieplnej poszczególnych składników często stosowane są również modele empiryczne wykorzystujące średnią geometryczną $[4,10,13]$ :

$$
\lambda_{\text {geom }}=\prod_{i=1}^{n} \lambda_{i}^{V_{i}}
$$

\section{Charakterystyka materiału badawczego}

Badania przeprowadzono dla piaskowców fliszowych warstw ciężkowickich i istebniańskich z otworu D-1. Dla wszystkich próbek określono wartość przewodności cieplnej próbki suchej i nasyconej, porowatość, gęstość szkieletową i objętościową oraz ilościowy skład mineralny.
Pomiary współczynnika przewodności cieplnej zrealizowane zostały metodą ustalonego przepływu ciepła, za pomocą aparatu FOX 50 firmy LaserComp, poprzez pomiar wielkości strumienia cieplnego przepływającego przez próbkę. Badania przewodności cieplnej wykonano w średniej temperaturze 
$25^{\circ} \mathrm{C}$, przy różnicy temperatur na płytach grzejnej i chłodzącej $20^{\circ} \mathrm{C}$. Pomiary przeprowadzono dla próbek suchych (próbki suszone 3 godziny w temperaturze $105^{\circ} \mathrm{C}$ ) i po nasyceniu wodą destylowaną. Gęstość szkieletową, gęstość objętościową oraz porowatość wyznaczono za pomocą dwóch współpracujących ze sobą aparatów AccuPyc 1330 oraz GeoPyc 1360 firmy Micromeritics. Analizę składu mineralnego przeprowadzono na podstawie ilościowej analizy rentgenowskiej opartej na metodzie Rietvelda [12] przy użyciu dyfraktometru rentgenowskiego X'Pert Pro firmy Panalytical.

Badane skały zawierają średnio około $62 \%$ kwarcu oraz duże ilości skaleni: średnio około 8\% plagioklazów i 17\% skaleni potasowych w piaskowcach ciężkowickich oraz $16 \%$ plagioklazów i 20\% skaleni potasowych w piaskowcach istebniańskich. Skały te charakteryzują się niewielkim zaileniem (z reguły poniżej $10 \%$ ), tylko w trzech próbkach reprezentujących warstwy istebniańskie zawartość minerałów ilastych przekracza $15 \%$. Węglany występują jedynie w części próbek, zawartość kalcytu jest zmienna: wynosi od 1\% do 13\%, a ilość dolomitu nie przekracza z reguły $1 \%$ (tablica 1 ). Współczynnik porowatości większości próbek mieści się w przedziale od 5\% do $11 \%$, niższymi wartościami porowatości cechuje się kilka próbek zawierających powyżej 7\% kalcytu (tablica 1).
Wartości współczynnika przewodności cieplnej $\lambda$ dla próbek suchych mieszczą się w przedziale $1,9 \div 3,3 \mathrm{~W} / \mathrm{mK}$ (tablica 1, rysunek 1). Przewodność cieplna większości próbek nasyconych waha się w granicach $3,2 \div 4,4 \mathrm{~W} / \mathrm{mK}$ (tablica 1, rysunek 1). Największe różnice pomiędzy wartościami przewodności cieplnej próbki suchej i nasyconej obserwuje się dla próbek o najwyższych porowatościach, co wynika z różnicy pomiędzy przewodnością cieplną powietrza i wody.

Wartość przewodności cieplnej zależy od wielu parametrów petrofizycznych skał, takich jak: porowatość, gęstość, skład mineralny czy uziarnienie $[6,14,15]$. Wpływ porowatości na przewodność cieplną jest wyraźnie widoczny w przypadku, gdy różnica między przewodnością cieplną szkieletu skały i medium nasycającego przestrzenie porowe jest znacząca, a więc dla pomiarów wykonanych na próbkach suchych (rysunek 2a), dla próbek nasyconych nie stwierdzono natomiast takiej zależności (rysunek $2 b$ ).

Wpływ składu mineralnego na przewodność cieplną przeanalizowano na podstawie korelacji z zawartością kwarcu. Przewodność cieplna próbki nasyconej (rysunek 3b) rośnie wraz z zawartością kwarcu, dla próbek suchych nie widać takiej zależności (rysunek 3a).

Tablica 1. Zestawienie wyników pomiarów porowatości i przewodności cieplnej oraz analizy ilościowej składu mineralnego badanych skał

\begin{tabular}{|c|c|c|c|c|c|c|c|c|c|c|c|c|c|c|c|}
\hline \multirow{2}{*}{ Stratygrafia } & $K p_{\text {Hel }}$ & $\lambda_{s}$ & $\lambda_{n}$ & Q & Pl & Sk-K & $\mathrm{C}$ & $\mathrm{D}$ & An & $\mathrm{P}$ & M & $\mathrm{Ch}$ & $\mathrm{K} 1$ & Suma & $\Sigma$ il \\
\hline & {$[\%]$} & \multicolumn{2}{|c|}{$[\mathrm{W} / \mathrm{mK}]$} & \multicolumn{12}{|c|}{$[\%]$} \\
\hline \multirow{13}{*}{ 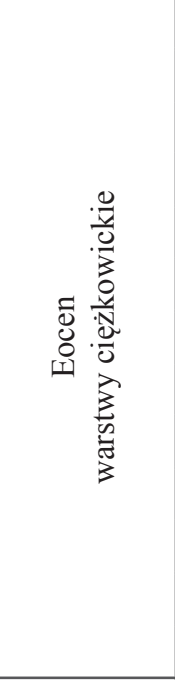 } & 7,38 & 2,56 & 3,51 & 45,0 & 7,1 & 2,8 & 8,5 & 18,6 & 4,0 & 1,0 & 8,1 & 2,0 & 1,9 & 100 & 13,0 \\
\hline & 10,22 & 2,34 & 3,73 & 73,3 & 5,6 & 12,5 & - & 0,4 & - & - & 5,3 & - & 2,9 & 100 & 8,2 \\
\hline & 10,73 & 2,59 & 4,16 & 78,1 & 5,9 & 10,9 & - & 0,8 & - & - & 2,7 & - & 1,6 & 100 & 4,3 \\
\hline & 11,08 & 2,66 & 3,85 & 70,9 & 4,7 & 18,5 & - & 0,3 & - & 0,8 & 2,7 & - & 2,1 & 100 & 4,8 \\
\hline & 4,27 & 2,98 & 4,25 & 53,0 & 5,7 & 14,1 & 11,3 & 1,5 & 1,2 & 1,3 & 9,7 & - & 2,2 & 100 & 11,9 \\
\hline & 11,08 & 2,45 & 4,38 & 70,4 & 7,2 & 16,8 & - & 0,5 & - & - & 2,7 & - & 2,4 & 100 & 5,1 \\
\hline & 7,82 & 2,85 & 4,60 & 70,5 & 9,5 & 17,3 & - & - & - & - & 2,1 & 0,6 & - & 100 & 2,7 \\
\hline & 12,2 & 2,23 & 3,27 & 65,0 & 9,0 & 19,5 & - & - & - & - & 3,9 & 1,3 & 1,3 & 100 & 6,5 \\
\hline & 11,22 & 2,33 & 3,64 & 69,9 & 8,3 & 14,1 & - & - & - & - & 4,9 & 1,8 & 1,0 & 100 & 7,7 \\
\hline & 9,17 & 2,65 & 3,49 & 59,8 & 11,3 & 20,3 & - & - & - & 0,6 & 4,2 & 3,0 & 0,8 & 100 & 8,0 \\
\hline & 0,53 & 3,07 & 4,17 & 51,4 & 6,8 & 19,4 & 12,9 & - & - & 1,0 & 6,9 & 1,0 & 0,6 & 100 & 8,5 \\
\hline & 6,75 & 2,56 & 3,47 & 63,4 & 10,9 & 16,7 & - & - & - & - & 5,2 & - & 3,8 & 100 & 9,0 \\
\hline & 5,34 & 3,19 & 4,40 & 65,0 & 9,7 & 19,2 & - & - & - & - & 3,9 & - & 2,2 & 100 & 6,1 \\
\hline \multirow{6}{*}{ 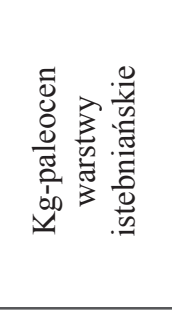 } & 5,86 & 2,76 & 3,66 & 56,5 & 10,8 & 22,9 & - & - & - & 1,0 & 3,5 & 3,2 & 2,1 & 100 & 8,8 \\
\hline & 7,56 & 2,99 & 4,39 & 67,1 & 12,7 & 3,9 & 0,9 & - & - & - & 7,7 & 5,8 & 1,9 & 100 & 15,4 \\
\hline & 6,31 & 1,88 & 2,11 & 28,0 & 23,1 & 13,4 & 1,4 & - & - & 1,5 & 26,7 & 5,2 & 0,7 & 100 & 32,6 \\
\hline & 10,81 & 1,86 & 3,29 & 51,3 & 16,6 & 23,8 & - & - & - & - & 6,0 & 2,3 & - & 100 & 8,3 \\
\hline & 2,17 & 3,19 & 3,21 & 41,8 & 15,9 & 22,0 & 11,6 & 0,3 & - & - & 6,6 & 1,8 & - & 100 & 8,4 \\
\hline & 1,11 & 3,34 & 4,29 & 55,8 & 15,9 & 22,7 & - & - & - & - & 2,2 & - & 3,4 & 100 & 5,6 \\
\hline
\end{tabular}

Objaśnienia: $K p_{\mathrm{Hel}}$ - porowatość; $\lambda_{s}$ - przewodność cieplna próbki suchej; $\lambda_{n}$ - przewodność cieplna próbki nasyconej; Q - kwarc; Pl-plagioklazy; Sk-K - skalenie potasowe; C - kalcyt; D - dolomit; An - ankeryt; P - piryt, M - miki i minerały z grupy illitu; Ch - chloryt; Kl - kaolinit, $\sum$ il - suma minerałów ilastych. 


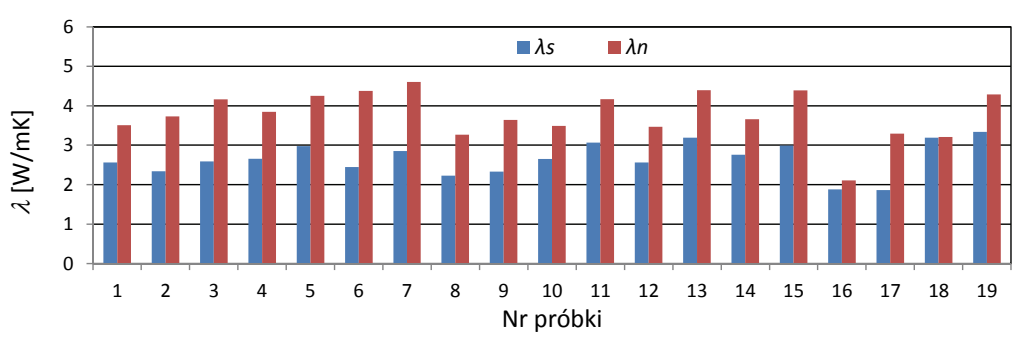

Rys. 1. Wartości współczynnika przewodności cieplnej piaskowców pomierzone na próbkach suchych $\left(\lambda_{s}\right)$ i nasyconych $\left(\lambda_{n}\right)$
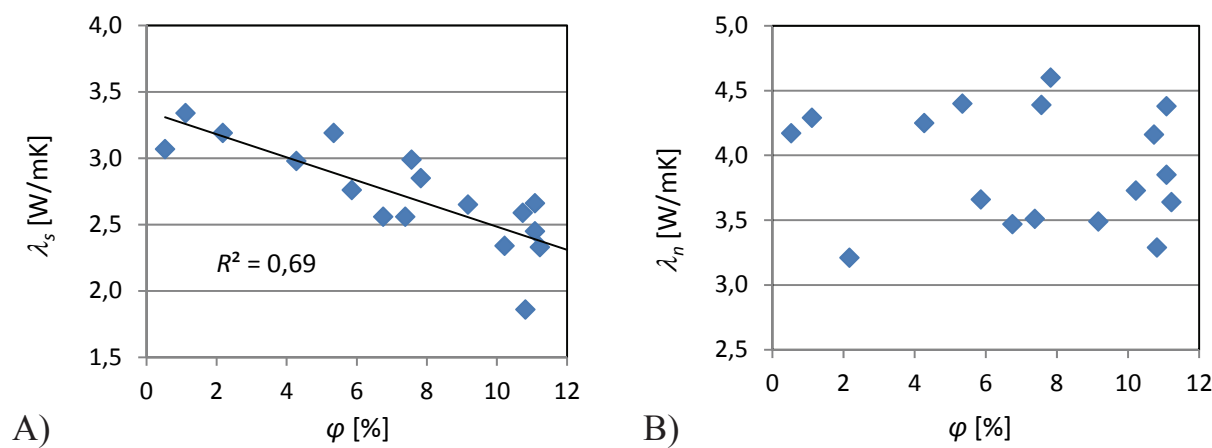

Rys. 2. A - zależność pomiędzy wartością przewodności cieplnej próbki suchej $\left(\lambda_{s}\right)$ a porowatością $(\Phi)$, przewodność cieplna powietrza $\lambda_{p}=0,025 \mathrm{~W} / \mathrm{mK} ; \mathrm{B}$ - zależność pomiędzy przewodnością cieplną próbki nasyconej $\left(\lambda_{n}\right)$ a porowatością $(\Phi)$, przewodność cieplna wody $\lambda_{w}=0,61 \mathrm{~W} / \mathrm{mK}$
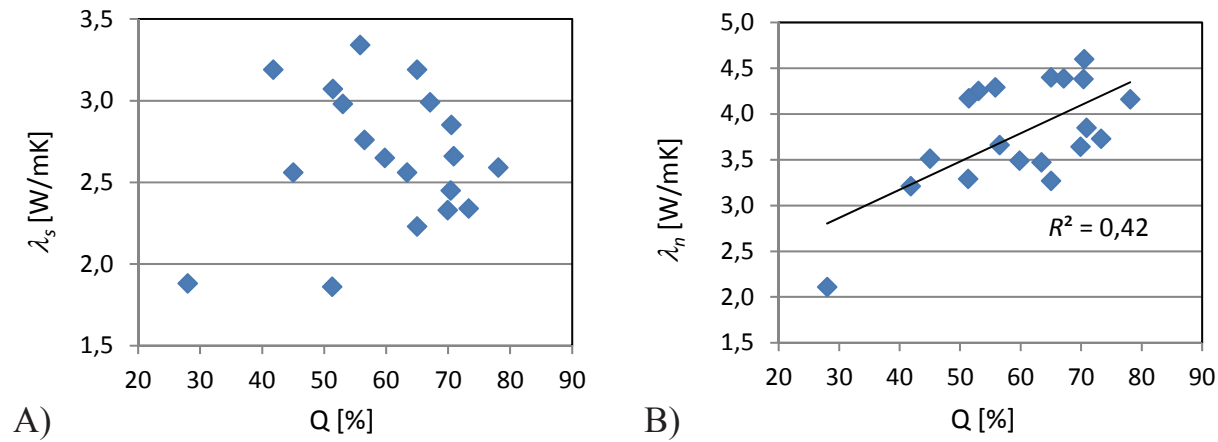

Rys. 3. A - zależność pomiędzy wartością przewodności cieplnej próbki suchej $\left(\lambda_{s}\right)$ a zawartością kwarcu $(\mathrm{Q})$;

B - zależność pomiędzy wartością przewodności cieplnej próbki nasyconej $\left(\lambda_{n}\right)$ a zawartością kwarcu (Q)

\section{Modele przewodności cieplnej}

Modelowanie wartości przewodności cieplnej skał przeprowadzono dla 19 próbek piaskowców fliszowych przy zastosowaniu opisanych powyżej równań.

Symbole stosowane w tekście:

$\lambda_{\text {lab }}-$ przewodność cieplna próbki nasyconej pomierzona laboratoryjnie,

$\lambda_{m}$ - przewodność cieplna matrix (szkieletu skały),

$\lambda_{m_{\text {_aryt }}}-$ przewodność cieplna szkieletu skały wyliczona za pomocą średniej arytmetycznej,

$\lambda_{m \_ \text {harm }}$ - przewodność cieplna szkieletu skały wyliczona za pomocą średniej harmonicznej,

$\lambda_{m \text { geom }}-$ przewodność cieplna szkieletu skały wyliczona za pomocą średniej geometrycznej,

$\lambda_{\text {aryt }}$ - przewodność cieplna skały nasyconej obliczona za pomocą średniej arytmetycznej, $\lambda_{\text {harm }}$ - przewodność cieplna skały nasyconej obliczona za pomocą średniej harmonicznej,

$\lambda_{\text {geom }}$ - przewodność cieplna skały nasyconej obliczona za pomocą średniej geometrycznej,

$\lambda_{\text {HS- }}-$ przewodność cieplna skały nasyconej obliczona przy zastosowaniu granic Hashina-Shtrikmana, dolna granica,

$\lambda_{\mathrm{HS}+}-$ przewodność cieplna skały nasyconej obliczona przy zastosowaniu granic Hashina-Shtrikmana, górna granica,

$\lambda_{\text {HS_srednia }}-$ przewodność cieplna skały nasyconej obliczona przy zastosowaniu granic Hashina-Shtrikmana, wartość średnia,

$\lambda_{s f m}$ - przewodność cieplna skały nasyconej obliczona przy zastosowaniu modeli inkluzji sferycznych, model Clausiusa-Mossottiego dla skały składającej się ze szkieletu ziarnowego i porów w postaci inkluzji sferycznych, 
$\lambda_{s f_{-} r} \quad$ - przewodność cieplna skały nasyconej obliczona przy zastosowaniu modeli inkluzji sferycznych, model Clausiusa-Mossottiego przy założeniu, że skała składa się ze sferycznych ziaren rozproszonych w roztworze porowym,

$\lambda_{s f \_ \text {śdnia }}$ - przewodność cieplna skały nasyconej obliczona przy zastosowaniu modeli inkluzji sferycznych, model Clausiusa-Mossottiego, wartość średnia.

Przyjęto następujący schemat działania:

1. Obliczenie przewodności cieplnej matrix (szkieletu ziarnowego) na trzy sposoby: za pomocą średniej arytmetycznej, harmonicznej i geometrycznej.

2. Określenie przewodności cieplnej próbki nasyconej za pomocą średniej arytmetycznej, harmonicznej i geometrycznej oraz porównanie uzyskanych wartości $\mathrm{z} \lambda_{\text {lab }}$.

3. Zastosowanie granic Hashina-Shtrikmana; w równaniach $\mathrm{H}-\mathrm{S}$ zaimplementowano wartości przewodności cieplnej szkieletu ziarnowego wyliczone za pomocą średniej geometrycznej, arytmetycznej i harmonicznej, a następnie porównano otrzymane wyniki z wartościami przewodności cieplnej pomierzony$\operatorname{mi}\left(\lambda_{\text {lab }}\right)$ oraz $\lambda_{\text {geom }}, \lambda_{\text {aryt }} \mathrm{i} \lambda_{\text {harm }}$.

4. Analiza uzyskanych wyników i wybór modelu właściwego dla obliczania przewodności cieplnej szkieletu ziarnowego skały w toku dalszych prac.

5. Określenie przewodności cieplnej próbki nasyconej za pomocą modeli inkluzji sferycznych (modele Clausiusa-Mossottiego).

Przewodność cieplną szkieletu skały obliczono na podstawie zawartości i przewodności cieplnej poszczególnych minerałów. Zawartość minerałów (\% wagowe) uzyskano na podstawie ilościowej analizy rentgenowskiej. Wartości przewodności cieplnej minerałów przyjęto według danych literaturowych $[1-3,11,16]$.

\section{Przewodność cieplna matrix (szkieletu ziarnowego)}

Wartości przewodności cieplnej szkieletu ziarnowego (rysunek 4) uzyskane za pomocą różnych modeli wykazują zasadniczo zbliżony trend, przy czym najniższe wartości obserwuje się dla modelu $\lambda_{m_{-} \text {geom }}$, a najwyższe dla modelu $\lambda_{m_{-} \text {aryt }}$.

\section{Modele warstwowe}

Porównanie $\lambda_{\text {aryt }} \mathrm{i} \lambda_{\text {harm }}$ wyliczonych dla próbki nasyconej z pomiarami laboratoryjnymi (rysunek 5) potwierdziło założenia teoretyczne: najwyższe wartości wykazuje $\lambda_{\text {aryt }}$ (model zakładający przepływ ciepła równolegle do warstw), a najniższe $\lambda_{\text {harm }}$ (model zakładający przepływ ciepła prostopadle do warstw). Wartości uzyskane na podstawie modelu $\lambda_{\text {geom }}$ plasują się pośrodku.

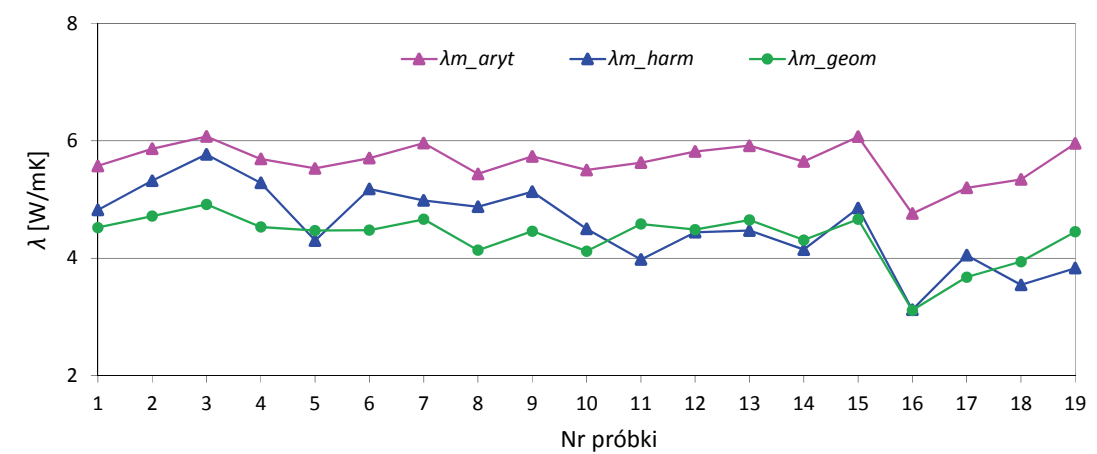

Rys. 4. Wartości przewodności cieplnej matrix uzyskane za pomocą średniej arytmetycznej $\left(\lambda_{m_{\_} \text {aryt }}\right)$, harmonicznej $\left(\lambda_{m_{\_} \text {harm }}\right)$ i geometrycznej $\left(\lambda_{m_{\_} \text {geom }}\right)$

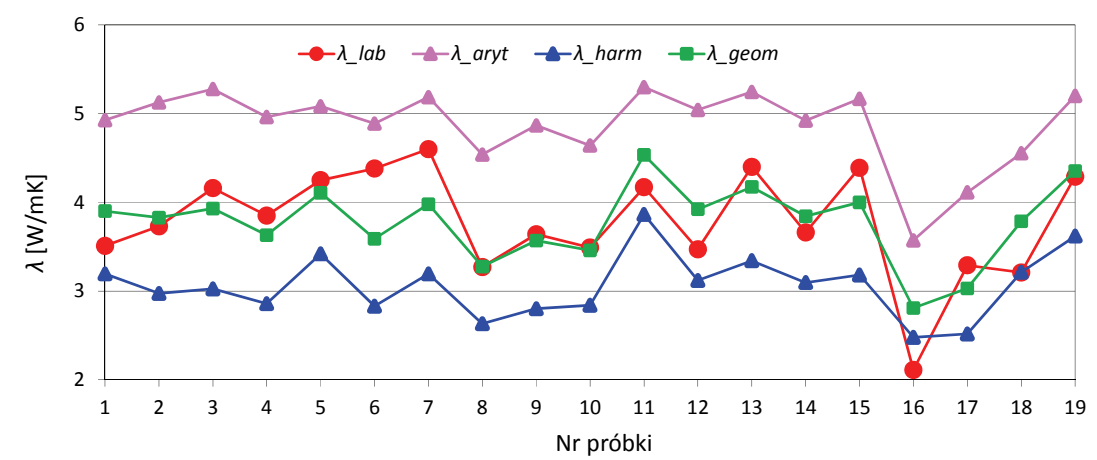

Rys. 5. Porównanie wartości przewodności cieplnej uzyskanych za pomocą średniej arytmetycznej $\left(\lambda_{\text {aryt }}\right)$, harmonicznej $\left(\lambda_{\text {harm }}\right)$ i geometrycznej $\left(\lambda_{\text {geom }}\right)$ $\mathrm{z}$ wartościami pomierzonymi laboratoryjnie
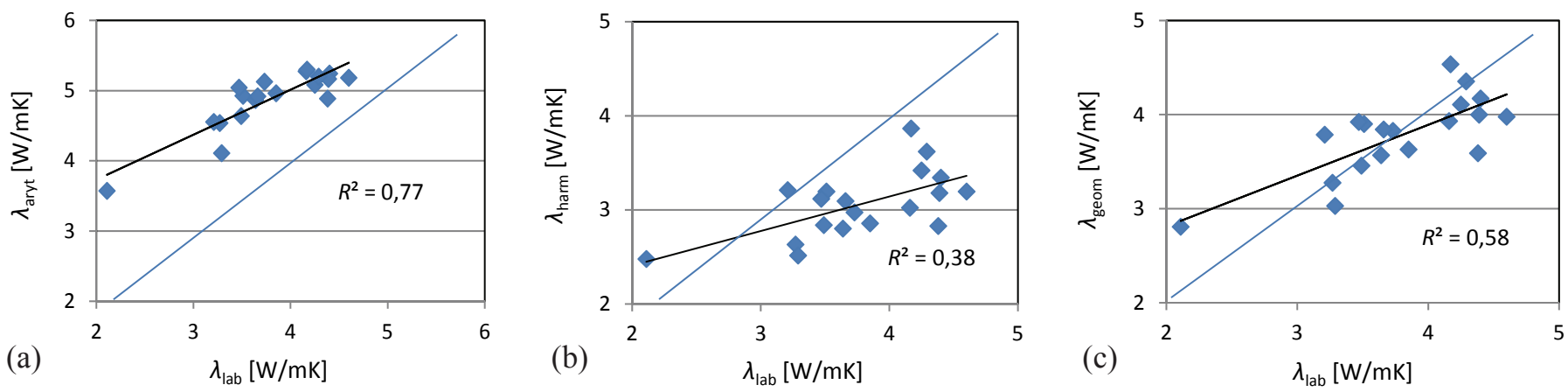

Rys. 6. Zależność pomiędzy wartościami przewodności cieplnej uzyskanymi za pomocą średniej arytmetycznej (a), harmonicznej (b) i geometrycznej (c) a wartościami pomierzonymi laboratoryjnie 
Najlepszą zgodność z wartościami pomierzonymi uzyskano na podstawie modelu $\lambda_{\text {geom }}$ (rysunki 5 i 6c). Wartości przewodności cieplnej otrzymane za pomocą modelu $\lambda_{\text {aryt }}$ wykazują co prawda dobrą korelację $\mathrm{z}$ wartościami pomierzonymi $\left(R^{2}=0,77\right)$, ale są od nich dużo wyższe (rysunek 6a).

\section{Granice Hashina-Shtrikmana}

Zastosowanie granic Hashina-Shtrikmana umożliwia dalsze zawężenie zakresu określonego przez modele warstwowe [4, 10, 18]. W równaniach $\mathrm{H}-\mathrm{S}$ zaimplementowano wartości przewodności cieplnej szkieletu ziarnowego wyliczone za pomocą średniej geometrycznej, arytmetycznej i harmonicznej, a następnie porównano otrzymane wyniki z wartościami przewodności cieplnej pomierzonymi $\left(\lambda_{\text {lab }}\right)$ oraz uzyskanymi za pomocą modeli $\lambda_{\text {aryt, }} \lambda_{\text {harm }} \mathrm{i} \lambda_{\text {geom. }}$. Prawidłowe wyniki otrzymano dla modeli, w których przewodność cieplną szkieletu skały wyliczono metodą średniej geometrycznej. W tym przypadku spełnione jest przytoczone powyżej teoretyczne założenie, że granice $\mathrm{H}-\mathrm{S}$ zawężają zakres wartości określony przez modele warstwowe, a równocześnie wartości pomierzone laboratoryjnie lokują się z reguły pomiędzy granicami HS+ i HS- (rysunek 7). Zastosowanie $\lambda_{m_{-} \text {aryt }}$ i $\lambda_{m \text { harm }}$ dało zdecydowanie zawyżone wartości HS+ i HS-. Uzyskane wyniki wskazały jednoznacznie na zasadność stosowania średniej geometrycznej do obliczania $\lambda_{m}$, metodę tę wykorzystano w kolejnych testowanych modelach.

Najlepszą zgodność z wartościami pomierzonymi otrzymano dla wartości $\lambda_{\text {HS- }}$ (rysunki 8,9 ). W przypadku próbek o bardziej gruboziarnistym charakterze (próbki nr 6 i 7) najlepiej dopasowuje się model $\lambda_{\mathrm{HS}^{+}}$(rysunek 8).

\section{Model inkluzji sferycznych Clausiusa-Mossottiego}

W dalszej kolejności przetestowano przydatność modelu inkluzji sferycznych Clausiusa-Mossottiego [16]. Najlepsze dopasowanie danych uzyskano dla średniej z obu modeli $\lambda_{s f \_s}$ (skała zbudowana ze szkieletu ziarnowego i porów w postaci inkluzji sferycznych) - rysunki 10 i 11c. Wartości otrzymane dla modelu $\lambda_{s f \_r}$ (skała składa się ze sferycznych ziaren rozproszonych $\mathrm{w}$ roztworze porowym) są $\mathrm{z}$ reguły nieco niższe od pomierzonych (rysunki $10 \mathrm{i} 11 \mathrm{~b}$ ), a w przypadku modelu $\lambda_{s f \_m}$ (skała zbudowana ze szkieletu ziarnowego i porów w postaci inkluzji sferycznych) nieco wyższe (rysunki 10 i 11a).

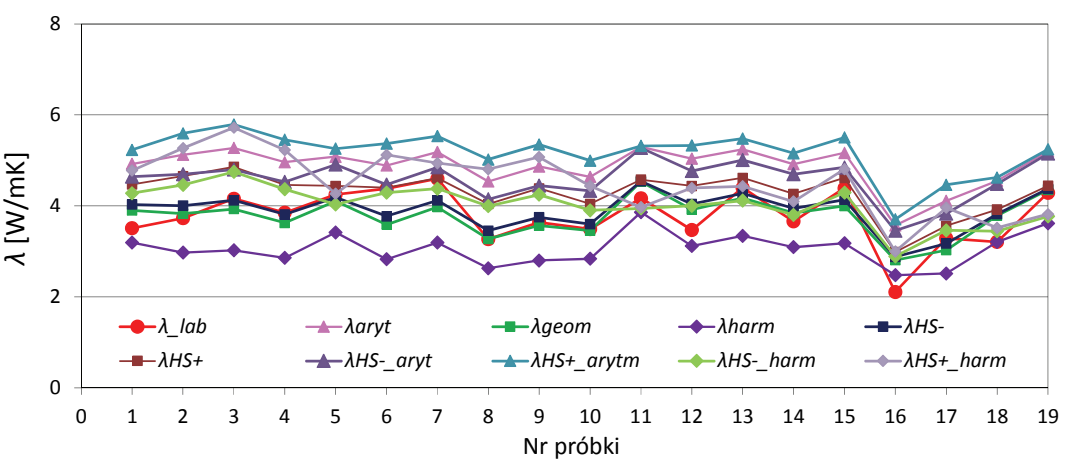

Rys. 7. Porównanie wartości przewodności cieplnej próbki nasyconej zyskanych za pomocą modeli H-S przy wykorzystaniu wartości lambda matrix wyliczonych za pomocą średniej geometrycznej $\left(\lambda_{\mathrm{HS}_{-}}, \lambda_{\mathrm{HS}^{+}}\right)$, $\operatorname{arytmetycznej}\left(\lambda_{\mathrm{HS}-\_ \text {aryt }}, \lambda_{\mathrm{HS+}+\text { aryt }}\right)$ i harmonicznej $\left(\lambda_{\mathrm{HS}_{-} \text {harm }}, \lambda_{\mathrm{HS}+\text { _harm }}\right)$ $\mathrm{Z}$ wartościami $\lambda_{\text {geom }}, \lambda_{\text {aryt }} \mathrm{i} \bar{\lambda}_{\text {harm }}$ oraz $\mathrm{z}$ wartościami pomierzonymi laboratoryjnie

Rys. 8. Porównanie wartości przewodności cieplnej próbki nasyconej zyskanych za pomocą modeli $\lambda_{\mathrm{HS}-}, \lambda_{\mathrm{HS}+}, \lambda_{H S \text { średnia }} \mathrm{i} \lambda_{\text {geom }} \mathrm{Z}$ wartościami pomierzonymi laboratoryjnie

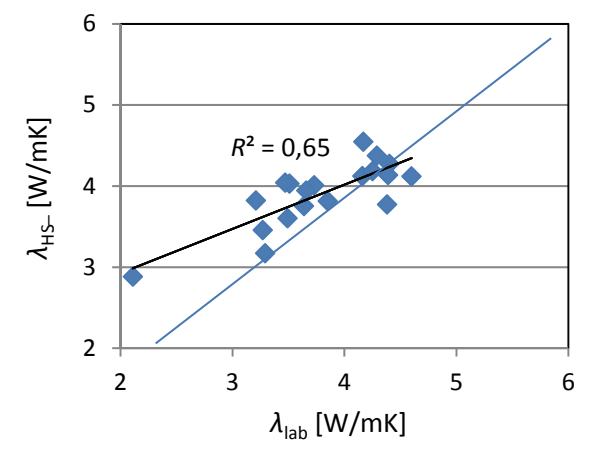

Rys. 9. Zależność pomiędzy wartościami przewodności cieplnej próbki nasyconej uzyskanymi za pomocą modelu $\mathrm{H}-\mathrm{S}$ a wartościami pomierzonymi laboratoryjnie

Wyniki uzyskane za pomocą równan $\mathrm{H}-\mathrm{S}$ i modeli Clausiusa-Mossottiego (opartych na tym samym teoretycznym modelu budowy skały - model sferycznych inkluzji) są zasadniczo zbieżne (rysunek 10), przy czym wartości otrzymane w przypadku modeli Clausiusa-Mossottiego są niższe niż dla modeli H-S. Najbardziej zbliżone są wartości wyznaczone na podstawie modelu $\lambda_{s f-m}$ oraz $\lambda_{s f \_ \text {srednia }}$ i HS-. 

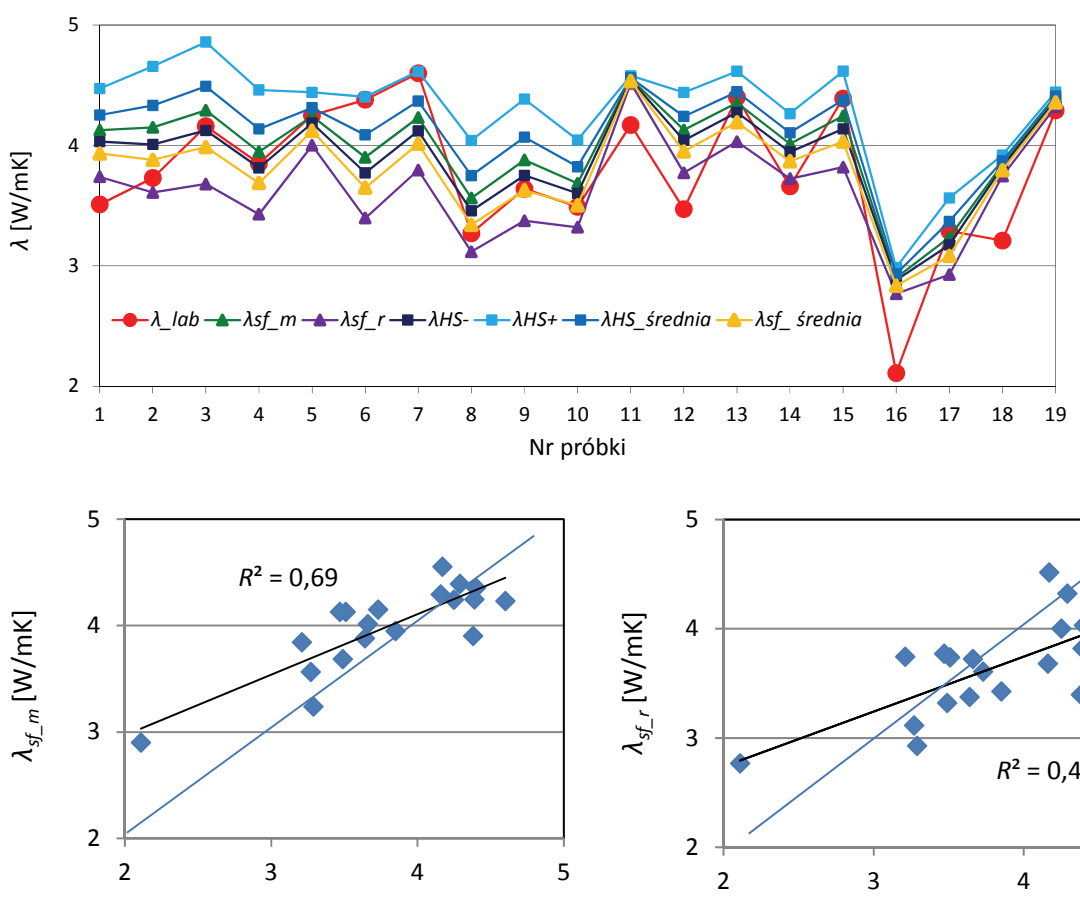

(a)

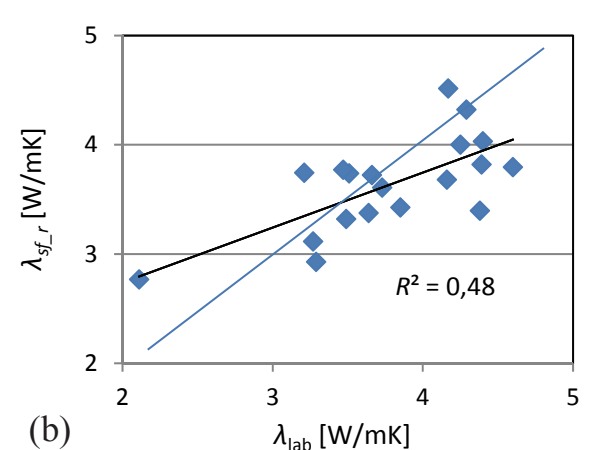

(b)

$\lambda_{\text {lab }}[\mathrm{W} / \mathrm{mK}]$

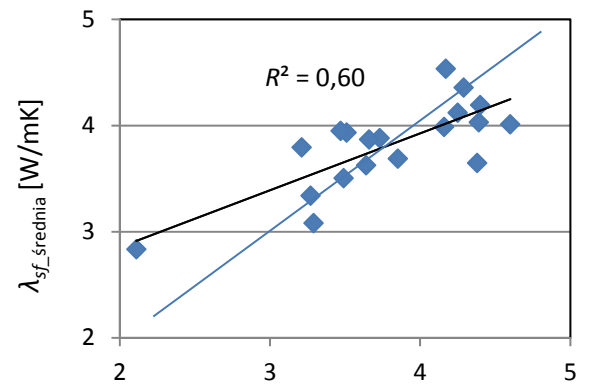

(c)
Rys. 10. Porównanie wartości przewodności cieplnej próbki nasyconej uzyskanych za pomocą modeli inkluzji sferycznych ClausiusaMossottiego, z wynikami otrzymanymi za pomocą równań $\mathrm{H}-\mathrm{S}$ oraz wartościami pomierzonymi laboratoryjnie

Rys. 11. Zależność pomiędzy wartościami przewodności cieplnej próbki nasyconej uzyskanymi za pomocą modeli inkluzji sferycznych $\lambda_{s f_{-} m}(\mathrm{a}), \lambda_{s f_{-} r}$ (b) i $\lambda_{s f_{-} s r}$ (c) a wartościami pomierzonymi laboratoryjnie

\section{Podsumowanie i wnioski}

W ramach przedstawionej pracy przeprowadzono analizę modeli matematycznych uwzględniających objętościową zawartość poszczególnych minerałów wraz z odpowiadającymi im współczynnikami przewodności cieplnej. Zastosowano różnego rodzaju modele, od najprostszych, zakładających warstwową budowę skały, do bardziej skomplikowanych modeli inkluzji sferycznych. Wartości obliczone porównano z wynikami pomiarów laboratoryjnych.

Pomierzone wartości współczynnika przewodności cieplnej $\left(\lambda_{\text {lab }}\right)$ w przypadku większości próbek nasyconych mieszczą się w przedziale $3,2 \div 4,4 \mathrm{~W} / \mathrm{mK}$. Wyniki obliczeń na ogół dobrze korelują z danymi laboratoryjnymi $\lambda_{\text {lab }}$. Najbardziej zbliżone wartości uzyskano dla modeli $\lambda_{\text {geom }} \mathrm{i} \lambda_{\text {HS- }}$. Dla modelu $\lambda_{s f \_} m$ otrzymano podobny współczynnik korelacji $\left(R^{2}=0,69\right)$, lecz nieco bardziej odbiegające wartości. Zaobserwowano wpływ litologii na dopasowanie wartości przewodności cieplnej ob- liczonych do pomierzonych laboratoryjnie. Większość badanych próbek to piaskowce drobnoziarniste o bezładnej strukturze (bez zaznaczającej się laminacji), dla tych skał dopasowanie wartości obliczonych i pomierzonych jest najlepsze. W przypadku kilku próbek o bardziej gruboziarnistym charakterze większość modeli daje wartości zaniżone, a najlepiej dopasowuje się model HS+, czyli model odpowiadający takiej geometrii skały, w której roztwór porowy ograniczony jest do sferycznych inkluzji w szkielecie ziarnowym.

Podsumowując, uzyskane wyniki umożliwiły dobór optymalnych modeli pozwalających na ocenę wartości przewodności cieplnej piaskowców fliszowych na podstawie składu mineralnego. Ocena wartości przewodności cieplnej na podstawie składu mineralnego daje szeroką możliwość uzupełnienia baz danych termicznych w przypadku wielu otworów, dla których były wykonywane standardowe badania mineralogiczne i petrofizyczne.

Prosimy cytować jako: Nafta-Gaz 2018, nr 6, s. 435-442, DOI: 10.18668/NG.2018.06.03

Artykuł nadesłano do Redakcji 11.12.2017 r. Zatwierdzono do druku 11.04.2018 r.

Artykuł powstał na podstawie pracy statutowej pt.: Szacowanie wartości współczynnika przewodności cieplnej skał o zróżnicowanej litologii na podstawie sktadu mineralnego - praca INiG - PIB na zlecenie MNiSW; nr zlecenia: 28/SW/17, nr archiwalny: DK-4100-15/2017.

\section{Literatura}

[1] Brigaud F., Vasseur G., Caillet G.: Thermal State in the North Viking Graben (North Sea). Geophysics 1992, vol. 57, nr 1, s. 69-88.

[2] Clauser C., Huenges E.: Thermal Coductivity of Rocks and
Minerals. [W:] Ahrens T.J. (ed.): Rock Physics and Phase Relations. A Handbook of Physical Constants. 1995.

[3] Demongodin L., Vasseur G., Brigaud F.: Anisotropy of Thermal Conductivity in Clayey Formations. Basin modelling: Advances 
and Applications (Norwegian Petroleum Society Special Publications) 1993, vol. 3, s. 209-217.

[4] Fuchs S., Balling N., Förster A.: Calculation of Thermal Conductivity, Thermal Diffusivity and Specific Heat Capacity of Sedimentary Rocks Using Petrophysical Well Logs. Geophysical Journal International 2015, vol. 203, nr 3, s. 1977-2000.

[5] Fuchs S., Schütz F., Förster H.J., Förster A.: Evaluation of common mixing models for calculating bulk thermal conductivity of sedimentary rocks: Correction charts and new conversion equations. Geothermics 2013, vol. 47, s. 40-52.

[6] Gąsior I., Przelaskowska A.: Charakterystyka parametrów termicznych skat mezopaleozoicznych z rejonu Kraków-Dębica. Nafta-Gaz 2010, nr 8, s. 663-667.

[7] Gąsior I., Przelaskowska A.: Estimating Thermal Conductivity from Core and Well Log Data. Acta Geophysica 2014, vol. 62, nr 4, s. 785-801, DOI: 10.2478/s11600-014-0204-y.

[8] Gegenhuber N., Schoen J.: New approaches for the relationship between compressional wave velocity and thermal conductivity. Journal of Applied Geophysics 2012, vol. 76, s. 50-55, DOI: 10.1016/j.jappgeo.2011.10.005.

[9] Goutorbe B., Lucazeau F., Bonneville A.: Using neural networks to predict thermal conductivity from geophysical well logs. Geophysical Journal International 2006, vol. 166, nr 1, s. 115-125, DOI: 10.1111/j.1365-246X.2006.02924.x.

[10] Hartmann A., Rath V., Clauser C.: Thermal conductivity from core and well log data. International Journal of Rock Mechanics \& Mining Sciences 2005, vol. 42, nr 7-8, s. 1042-1055, DOI: 10.1016/j.ijrmms.2005.05.015.

[11] Horai K.I.: Thermal Conductivity of Rock Forming Minerals. Journal of Geophysical Research 1971, vol. 76, nr 5, s. 1278-1308.
[12] Kowalska S.: Określenie ilościowego składu mineralnego skat zawierajacych mineraty ilaste metoda Rietvelda. Nafta-Gaz 2013, nr 12, s. 894-902.

[13] Middleton M.: Determination of Matrix Thermal Conductivity from Dry Drill Cuttings. AAPG Bulletin 1994, vol. 78, nr 11, s. $1790-1799$.

[14] Midttomme K., Roaldset E., Aagard P.: Thermal conductivity of selected claystones and mudstones from England. Clay Minerals 1998, vol. 33, nr 1, s. 131-145.

[15] Plewa S., Plewa M.: Petrofizyka. Wydawnictwo Geologiczne, Warszawa 1992.

[16] Schön J.H.: Physical Properties of Rocks. Handbook of Petroleum Exploration and Production 2011, vol. 8

[17] Szewczyk J.: Estymacja gęstości strumienia cieplnego metoda modelowań wtaściwości termicznych ośrodka. Przegląd Geologiczny 2001, vol. 49, nr 11, s. 1083-1088.

[18] Zimmerman R.W.: Thermal Conductivity of Fluid-Saturated Rocks. Journal of Petroleum Science and Engineering 1989, vol. 3, nr 3, s. 219-227.

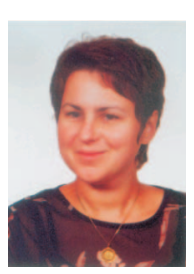

Mgr Anna PRZELASKOWSKA

Starszy specjalista badawczo-techniczny

w Zakładzie Geofizyki Wiertniczej.

Instytut Nafty i Gazu - Państwowy Instytut Badawczy

ul. Lubicz 25 A

31-503 Kraków

E-mail: anna.przelaskowska@inig.pl

\section{OFERTA}

\section{ZAKŁAD SEJSMIKI}

Zakres działania:

- interpretacja strukturalna i litofacjalna zdjęć sejsmicznych 2D i 3D;

- $\quad$ przetwarzanie danych sejsmicznych 2D/3D Prestack i Postack

- $\quad$ migracja sejsmiczna MGF-K w wersji Prestack i Postack w domenie czasu i głębokości z uwzględnieniem anizotropii ośrodka typu VTI, TTI, HTI;

- interpretacja strukturalna i litofacjalna pomiarów sejsmicznych Prestack i Postack 2D oraz 3D;

- $\quad$ przetwarzanie i interpretacja pionowych profilowań sejsmicznych PPS 1C, 3C;

- budowa modeli predkościowych na podstawie analiz danych sejsmicznych i geofizycznych w domenie czasu i głębokości - konwersja czas-głębokość, migracja głębokościowa:

- $\quad$ interpretacja danych sejsmicznych 3D-3C oraz pomiarów sejsmiki otworowej PPS-3C;

- $\quad$ konstrukcja map powierzchniowych - czasowych i głębokościowych;

- $\quad$ zwiększenie dokładności identyfikacji ośrodka geologicznego poprzez modyfikacje charakterystyki widmowej zarejestrowanych danych sejsmicznych

- $\quad$ poprawa rozdzielczości danych sejsmicznych Postack - dekompozycja spektralna;

- wieloatrybutowa charakterystyka ośrodka geologicznego;

- $\quad$ analizy sejsmiczne AVO, AVAZ

- obliczanie inwersji symultanicznej oraz stochastycznej;

- $\quad$ wykonywanie modelowania sejsmicznego;

- identyfikacja anizotropii typu HTI w ośrodku geologicznym przy użyciu danych sejsmicznych i otworowych - określenie intensywności oraz azymutu anizotropii;

- $\quad$ obliczanie parametrów anizotropii typu VTI i HTI oraz określenie głównych kierunków szczelinowatości na podstawie wieloazymutalnego pomiaru PPS 3C i sejsmiki powierzchniowej;

- $\quad$ wyznaczanie poziomów złożowych (bright, dim oraz sweet spot) na danych Prestack oraz Postack;

- zastosowanie metod geostatycznych do konstrukcji statycznych i dynamicznych modeli złóż węglowodorów:

- $\quad$ prognozowanie ciśnień porowych na podstawie danych sejsmicznych i geofizycznych.

P. o. Kierownika: mgr inż. Aleksander Wilk

Adres: ul. Bagrowa 1, 30-733 Kraków

Telefon: 126177480

Faks: 126531665

E-mail: aleksander.wilk@inig.pl 